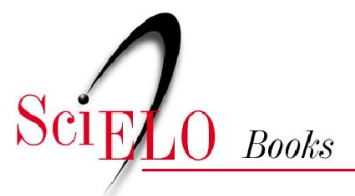

\title{
Denmark
}

\author{
Bruno Hansen
}

SciELO Books / SciELO Livros / SciELO Libros

HANSEN, B. Denmark. In SORJ, B., CANTLEY, M., and SIMPSON, K., eds. Biotechnology in Europe and Latin America: prospects for co-operation [online]. Rio de Janeiro: Centro Edelstein de Pesquisas Sociais, 2010. pp. 37-45. ISBN: 978-85-7582-036-6. Available from SciELO Books $<\underline{\text { http://books.scielo.org }>\text {. }}$

\section{(1) $(0)$}

All the contents of this chapter, except where otherwise noted, is licensed under a Creative Commons Attribution-Non Commercial-ShareAlike 3.0 Unported.

Todo o conteúdo deste capítulo, exceto quando houver ressalva, é publicado sob a licença Creative Commons Atribuição Uso Não Comercial - Partilha nos Mesmos Termos 3.0 Não adaptada.

Todo el contenido de este capítulo, excepto donde se indique lo contrario, está bajo licencia de la licencia Creative Commons Reconocimento-NoComercial-CompartirIgual 3.0 Unported. 


\subsection{DENMARK}

Bruno Hansen

\section{Introduction}

Biotechnology has a long tradition in Denmark. Substantial funds have been devoted to research in both private and public sectors. Modern biotechnology is used in many different areas of industry and in the public sector.

The following review emphasises applications of the latest developments in biotechnology in the following sectors.

1. Manpower in molecular biology and biotechnology;

2. Public institutions including universities performing research in molecular biology and biotechnology;

3. Biotechnological industries and their research;

4. Government funded research programmes in molecular biology and biotechnology;

5. International collaboration;

6. Legislation concerning control of research and production.

\section{Manpower in Molecular Biology and Biotechnology}

Graduates in molecular biology are produced at the universities of Copenhagen, Aarhus and Odense, but most workers in the field are graduates from other institutions which have a molecular biological component in their curriculum as summarised in the table below.

\begin{tabular}{|lc|}
\hline Table 1. Output of potential workers in biotechnology & \\
\hline Institution (s) & $\begin{array}{c}1987 \\
\text { Number of } \\
\text { Graduates }\end{array}$ \\
\hline $\begin{array}{l}\text { Universities of Copenhagen, Aarhus, Odense: } \\
\text { graduating in molecular biology, biochemistry, biology and } \\
\quad \text { chemistry }\end{array}$ & 215 \\
$\quad$ graduating in medicine & 560 \\
$\begin{array}{l}\text { Danish Technical University: } \\
\text { graduates in chemical engineering }\end{array}$ & 70 \\
$\begin{array}{l}\text { Royal Danish School of Pharmacy } \\
\text { graduates in pharmacology }\end{array}$ & 70 \\
$\begin{array}{l}\text { Royal Danish Veterinary and Agricultural University } \\
\text { graduates I veterinary science, agronomy, food technology, }\end{array}$ & 275 \\
$\quad$ horticulture, dairy science & 1190 \\
\hline
\end{tabular}

Clearly the total is large enough to support a considerable expansion of Denmark's biotechnology activity. All of the above institutes also offer advanced training and degrees, but a lack of training grants and facilities has limited intake.

The bottlenecks have been identified as limited facilities and staff at senior level, but the enthusiastic response of Denmark's scientific community to the new biotechnology indicates considerable scope for expansion.

The new biotechnology programme aims to substantially increase research training in biotechnology. The scientific manpower available to support the programme has a broad base of appropriate competence. The tendency of Danish scientists to have spent time in foreign laboratories adds further to the experience base of Danish biotechnology.

\section{Public Institutions Including Universities Performing Research in Molecular Biology and Biotechnology}

\section{UNIVERSITIES}

As mentioned above all of the institutions shown in Table 1 carry out research and award higher degrees. Some of the laboratories have achieved international distinction. 
Basic operating funding for university linked institutes and laboratories comes from the university research budget, which is almost entirely provided by the government. To supplement the government funds there is competition for funds from agencies which include research councils, private foundations, government research initiatives and international initiatives such as the European Commission's Biotechnology Action Programme.

Almost all of the universities are involved in active collaboration, either with other universities and institutes at home and abroad or with industry both at home and abroad.

GOVERNMENT RESEARCH INSTITUTES ETC.

Ministry of Interior Affairs: At the Government Serum Institute, high level research is dedicated to the production of diagnostics, sera and vaccines. The University Hospital in Copenhagen works in close cooperation with the medical faculty at the University and with other hospitals especially those in university cities.

Ministry of Agriculture: Gives support to several institutes active in biotechnology, notably the Veterinary Serum Laboratory in Copenhagen, The Institute for Veterinary Virus Research at Lindholm and the Research Institute for Animal Husbandry at Foulum.

Ministry of Fisheries: The Institute for Fish Research at Lyngby and Hirtshals and the Fishery and Sea Investigations at Hirtshals are both active in aspects of aquatic biotechnology.

Ministry of Energy: At the Research Establishment in Riso plant biotechnology and especially protoplast technology is the focus of effort.

Ministry of Environmental Affairs: Has a largely supervisory role. Research funding is not a primary objective.

Ministry of Labour: At the National Institute of Occupational Health, steps have been taken to initiate a programme in gene technology and health care problems in related to modern biotechnological procedures.

Ministry of Industry: Several programmes support R\&D in biotechnology. Support is given to Technological Service Institutes, independent, non-profit institutes working in co-operation with industry and in some fields with the public sector. Several such institutes are active in biotechnology, especially those sponsored by the Academy for Technical Services, ATV. Notable are, the Gene Technology Laboratory, Lyngby, the Danish Aquaculture Institute, Horsholm and the Institute for Biotechnology, Kolding.

\section{Biotechnological Industries and Their Research}

Alfred Benzon A/S

A small highly specialised company operating in the molecular biology and active peptide sector. Major R\&D commitment.

Danisco A/S

Investing heavily in biotechnology, Danisco and its subsidiaries are involved in the production of enzymes, emulsifiers food additives and sewage treatment.

De Danske Sukkerfabrikker A/S

Active in plant genetics and membrane technology. Passage of new rDNA regulations has prevented field trials (in Denmark) of genetically modified sugar beet.

\section{Chr Hansens Laboratorium A/S}

Involved in production of chymosin and lactic acid bacteria cultures.

Novo Industry $A / S$

Novo is a major producer of insulin and industrial enzymes. With about 4.000 employees in Denmark, Novo is by Danish standards a big company. Almost all biotechnological activities are undertaken by Novo, and R\&D represents a very large proportion of total turnover.

\section{Nordisk Gentofte}

Is also involved in Insulin production. Other products include peptide and protein pharmaceuticals including human growth hormone, serum albumin and factor VIII.

\section{United Breweries}

Include the Carlsberg Research Centre and Carlbiotech. This company has a long tradition of innovation and investment in biotechnology. Products and interests include: enzymes, hormones, plant molecular genetics, fermentation and protein engineering. 
Other companies

Include; Aarhus Oliefabrik, Convex Biotechnology, Dansk Sojaakagefabrik, L Dxhnfeldt, Ferrosan, Fredericia Cellulosefabrik, Kobenhavns Pektinfabrik, Lundbeck.

Almost all Danish biotechnology companies are involved in formal or informal relationships with universities and government research institutes. Personal contact plays an important role in establishing these important networks. Expensive instrumentation is often shared.

\section{Government Funded Research Programmes in Molecular Biology and Technology}

In a well established pattern, the research councils have provided funds for scientific research in many areas including molecular biology and biotechnology. Applications for such funds are competitive.

The Ministry of Industry through its Agency of Technology has supported biotechnology through a number of programmes. Two in particular were specifically designed to support biotechnology.

THE RESEARCH PROGRAMME FOR BIOMOLECULAR TECHNIQUE

Approved in June 1984 Parliament voted DKr33.6 million for a five year programme of research administered by the research councils.

\begin{tabular}{|lccccc|}
\hline Table 2. The following appropriations have been made so far. \\
\hline \multicolumn{7}{|c|}{ DKr 1000 } \\
Biorganic chemistry & 1984 & 1985 & 1986 & 1987 & 1988 \\
Biostructural chemistry & 880 & 741 & 770 & 870 & 870 \\
Genetic stability & 400 & 818 & 850 & 850 & 850 \\
Purification & 775 & 767 & 860 & 1010 & 1010 \\
Plant cells & 150 & 460 & 690 & 840 & 840 \\
Plant genes & 400 & 511 & 679 & 680 & 680 \\
Reproductive biology & 0 & 1022 & 1158 & 1160 & 1160 \\
Reagents and vaccines & 300 & 734 & 884 & 1035 & 1035 \\
Total & 0 & 460 & 901 & 1150 & 1150 \\
\hline
\end{tabular}

RESEARCH AS A BASIS FOR TECHNOLOGICAL DEVELOPMENT

Approved by parliament in 1985, this five year programme totals DKr300 million, with biotechnology getting DKr 60 million. The research councils administer the funds.

THE NEW BIOTECHNOLOGY PROGRAMME

Proposed by the government in 1986, funds were approved in principle in 1987, but at the time of writing final programme approval has not been given, and the following outline is necessarily provisional.

THE DANISH PROGRAMME FOR BIOTECHNOLOGY 1987-1990

\section{Introduction}

The recent advances in biological sciences have profound implications for applied biology and for Danish production and export, as well as for the environment, health care and nutrition.

Denmark must secure an independent competence in biotechnology, characterised by an intensified national effort. The proposed national programme has three main elements:

- Biotechnology Research Centres

- Education

- Information and technology assessment 
The programme will have a broad based steering committee with representatives from the ministries, universities and industry.

Biotechnology Research Centres will form the core of the programme. The establishment of 6-10 centres is visualised. A centre would not be a physical structure, but the formalised association of research groups in institutes and industry. For a country which until recently had a clear rift between universities and industry this is a major step. The achievement of an intellectual critical mass is one of the objectives of such centres.

Technology transfer from university to industry would be facilitated by the centres leading to rapid commercialisation of research work.

A call for applications for grants was distributed. Applications contain information on the qualifications of participating scientists, the nature of the projects and proposed budgets. The biotechnology programme is intended to supply only part of the costs, essential infrastructure being provided by the participants. Grants would be given for the whole funding period, and holders would have considerable flexibility to target fund according to changing project requirements. This requires a radical change away from closely monitored research funds.

The centres will concentrate on disciplines such as: biochemistry, molecular genetics, immunology, growth physiology, microbiology, bioindustrial processing technology and research must be directed to optimisation of microorganism, cell cultures and molecular biology applications.

Each centre will focus upon a large area and funding will depend upon the quality and distribution of the applicants. It is intended that the following areas be covered:

- Molecular biology, biotechnological methods and processes

- Fermentation and down stream processing

- Plant production

- Animal production

- Marine biology, fish farming, use of aquatic resources

- Food production

- Environmental protection, ecology, use of waste products

- Health care
At the time of writing more than 50 applications had been received, covering the whole target area.

\section{Education}

There must be an increase in the supply of biotechnologists. Part of the programme appropriation is aimed at increasing the output of MS level graduates in relevant subjects.

DKr60 million has been budgeted for education in the programme to be used in the following way:

\begin{tabular}{|lcccc|}
\hline & \multicolumn{4}{c|}{ DKr million } \\
\cline { 2 - 5 } & 1987 & 1988 & 1989 & 1990 \\
\hline Final year undergraduate stipends & 6.0 & 8.0 & 8.0 & 8.0 \\
Bottleneck courses & 2.0 & 2.0 & 2.0 & 2.0 \\
Curriculum development & 3.5 & 2.5 & 1.0 & 1.0 \\
Retraining & 4.5 & 4.5 & 2.0 & 2.0 \\
Instrumentation for education & 4.0 & 3.0 & 2.0 & 2.0 \\
Total & 20.0 & 20.0 & 15.0 & 15.0 \\
\hline
\end{tabular}

The aim of the funding described above is to increase the production of relevant graduates to a level of 150-200 per year, increasing to 300 by 1990 .

Ph.D. level research will take place in research centres, which will be obliged to have a number of graduate students on their staffs. The centres will also have to arrange courses, workshops etc for other scientists.

\section{Information and Technology Assessment}

There has been much concern in Denmark over the risks and ethical concerns involved in biotechnology. Public information is a key need. Research must also be undertaken to evaluate the implications of biotechnology for the economy, the environment, public health and nutrition.

The information programme will focus on providing the public with more and better material on molecular biology and biotechnology. This should not take the form of 'official information'. Translation of key literature into Danish could play a part of the programme. Existing information channels, including schools, public libraries etc. will be used for distribution. Access to international studies on technology assessment will be facilitated. The objective is to provide a coherent background for the ongoing debate. 
Overall Programme Budget

The following appropriation has been made for the National Biotechnology Programme:

\begin{tabular}{|lccccc|}
\hline & \multicolumn{5}{c|}{ DKr million } \\
\cline { 2 - 6 } & 1987 & 1988 & 1989 & 1990 & Total \\
\hline Research centres & 50 & 100 & 130 & 130 & 410 \\
Education & 20 & 20 & 15 & 15 & 70 \\
Information and & 5 & 5 & 5 & 5 & 20 \\
technology assessment & 75 & 125 & 150 & 150 & 500 \\
Totals & & & & & \\
\hline
\end{tabular}

\section{International Collaboration}

Several Danish institutions and companies participate in the EEC Biotechnology Action Programme 1985-1989. Denmark is also a member of the European Molecular Biology Laboratory, EMBL, and is playing an active role in the EUREKA programme. A Nordic collaborative programme in biotechnology is being considered, and is seeing first fruits in agreements on protein engineering. Co-ordination of international co-operation and national programmes is a high priority.

\section{Legislation Concerning the Control of Research and Production}

In 1986 Denmark was the first country to enact legislation to regulate genetic manipulation (an official English translation is available). The law is wide reaching and precise details of interpretation will depend upon existing regulatory procedures. The law is administered by the Ministry of Environmental Affairs. 